\title{
KÖRÖMI GABRIELLA
}

\section{A drámai forma megjelenése Guy de Maupassant dialógusos novelláiban}

Mártának

„Az írástudók azt mondják, hogy nincs értelme Régi idôk történetét megírni, Ha nem latinul irom, És végül is elvesztegetem az időm. Azok vesztegetik el, akik nem csinálnak semmit."

Partonopeu de Blois ${ }^{1}$

Guy de Maupassant-t prózaíróként, azon belül is elsősorban novellaíróként tartja számon az irodalomtörténet és az olvasóközönség egyaránt. Ma már kevésbé vagy talán egyáltalán nem ismert, hogy a modern novella atyjának nevezett Maupassant verseket és színdarabokat is írt. Életművének e szegmensei esztétikai-irodalmi érték, múvészi élmény tekintetében messze elmaradnak prózai munkáitól, azokat ma már kizárólag az irodalmárok ismerik és olvassák.

Tanulmányom célja Maupassant azon novelláinak a vizsgálata, amelyek müfaj-kereszteződésből születtek, azaz egyszerre az epika és a dráma jellegzetességeit is magukban hordják. Ehhez azonban elengedhetetlen a magyar olvasók számára ismeretlen költő és drámaköltő Maupassant bemutatása.

Maupassant tizenhárom éves korában kezdett verseket írni, de a kamaszkori verselésnek induló alkotói tevékenység közel két évtizeden át elkísérte. Egyik leghíresebb életrajzírója, Armand Lanoux írta róla: „Kevés költő akadt, aki ennyire nem volt költő, és mégis ennyi verset írt." Maupassant egyetlen verseskötete 1880-ban jelent meg, ${ }^{3}$ tíz nappal a Médani esté $k^{4}$ után. A többszerzős novellagyüjtemény megjelenésekor

1 Halász Katalin fordítása. Lásd: HaLÁsz Katalin, Egy müfaj születése - A középkori francia regény, (Debrecen: Kossuth Egyetemi Kiadó, 1998), 47.

2 Lanoux, Armand, Maupassant, a Szépfiú, ford. RÉvfy Tivadar, (Budapest: Európa Könyvkiadó, 1974), 32.

3 Maupassant a kötetet Gustave Flaubert-nek ajánlotta. Lásd: Guy de Maupassant, Des vers, (Paris: Charpentier, 1880).

4 A Médani esték c. kötet, amelyet Émile Zola szerkesztett, hat naturalista író - Émile Zola, Guy de Maupassant, J.-K. Huysmans, Henry Céard, Léon Hennique és Paul Alexis - a francia-porosz háborúról írt novelláját tartalmazta. Az antológia legsikerültebb írása vitathatatlanul Maupassant 
mesterének, Gustave Flaubert-nek írt leveléből kiderül, hogy Maupassant a kötetben publikált Gömböc címú novelláját csupán az akkor még megjelenés előtt álló verseskötete "tökéletes előkészitésének” tartotta, azaz számára egyértelműen ez utóbbi volt az elsődleges. Maupassant csak a Versek kudarcának ${ }^{6}$ és a Gömböcátütő sikerének együttes hatására fordított végleg hátat a lírának. ${ }^{7}$ Költészetének tanulmányozása ugyanakkor az irodalomtörténészek szerint egyáltalán nem érdektelen. Egyrészt azért, mert már korai verseiben is fel-felvillannak azok a témák - a természet szeretete, féktelen szabadságvágy, férfi és nő közötti meg nem értés, egy láthatatlan hasonmás nyugtalanító jelenléte -, amelyek később vezérmotívumként vonulnak végig novelláiban. Másrészt azért, mert versei irodalomtörténeti kuriózumnak számítanak, hiszen, ahogyan Louis Forestier írta: „[...] Maupassant egyike azon ritka íróknak, akik megmutatták, milyen lehetett volna egy naturalista költészet".

Habár a Gömböc előtt barátai - és szinte kizárólag ők - csak a verseit ismerték, Maupassant azokban az években elsősorban mégsem költői, hanem színmüírói ambíciókat dédelgetett. A színdarabok iránti vonzódása minden bizonnyal gyermekkorában gyökerezett: édesanyja a „liberális nevelés” jegyében a Szentivánéji álmot és a Machbetet olvasta fel neki. A hetvenes évek végétől étretat-i villájukban, a kor szokásainak megfelelően, gyakran tartottak házi színielőadásokat, rögtönöztek komikus jeleneteket, farce-okat, amelyekben Maupassant rendezőként, dramaturgként és színészként is részt vett. Az irodalmi pályára Gustave Flaubert irányításával készülő Maupassant azzal is tisztában volt, hogy sikeres színmüíróként nemcsak biztos megélhetésre, de ismertségre is szert tehet, hiszen a 19. században általában, a század második felében pedig különösen, a színházművészet uralta a párizsi kulturális életet, a bulvárszínházaktól az arisztokrata szalonokig bezárólag. Nem véletlen, hogy a kor összes jelentős prózaírója kipróbálta magát a színmüírásban. ${ }^{10}$

Gömböc c. novellája volt, amely egy csapásra ismertté tette szerzője nevét. A kötet 1880. április 17-én jelent meg.

5 Lásd az 1880. április végén Gustave Flaubert-nek írt levelét. „C’est une préparation parfaite à mon volume de vers." (A tanulmányban idézett Maupassant levélrészleteket saját fordításban adjuk meg.) Guy de Maupassant, Correspondance, éd. Jacques Suffel, (Évreux: Le Cercle du bibliophile, 1973), 1: 276.

6 A korabeli kritika ugyan pozitívan fogadta a kötetet, de eladási szempontból bukás volt. Kevesebb mint egy hónappal a megjelenés után a kiadó lecseréltette az eladatlan példányok borítóját, és az új borítóra a „második kiadás” feliratot nyomtattatta.

71880 után Maupassant már csak néhány rövid, nem publikálásra szánt alkalmi vagy erotikus verset írt.

8 „[...] Maupassant est l'un des rares écrivains à donner l'idée de ce qu'aurait pu être une poésie naturaliste.” Louis FORESTIER, „La lyre et le projecteur”, Magazine littéraire 310, (1993): 76-80, 78.

9 Lanoux, Maupassant..., 25.

10 A korabeli pezsgő párizsi színházi életet jól érzékeltetik Frederic Hemmings számai: a 19. század során a francia fơvárosban 32000 darabot mutattak be; 1888-ban ötszázezer párizsi hetente egyszer, 
1874-79 között Maupassant négy színdarabot, egy drámát és három komédiát írt, közülük hármat verses formában. ${ }^{11}$

Drámaírói álmai ellenére Maupassant színházhoz való viszonya, ahogyan arról barátainak, anyjának írt levelei tanúskodnak, rendkívül ellentmondásos volt: hol annak a meggyőződésének adott hangot, hogy az irodalmi babérokat a színház hozza majd meg számára, hol azt állította, hogy semmi keresnivalója nincs ebben a műfajban, amelyhez nem ért. Flaubert tanítványától ez egyáltalán nem meglepő: a mester színházról alkotott felfogása határozottan negatív volt, nemcsak a színházi szakembereket, de a színmüírást is lenézte, olyan tevékenységnek tartotta, amelyet az igazi művészek, esztéták nem művelnek. ${ }^{12}$ Maupassant jó tanítvány volt, átvette mestere színházzal szembeni előítéletét (is).

A maupassant-i életmű vizsgálata egyértelmủen bizonyítja, hogy az írónak sohasem sikerült feloldania a színházhoz való konfliktusos viszonyát, hiszen úgy gyakorolta a drámaírást, hogy mưvei nem nélkülözték saját színházellenességének a nyomait. Ennek az ellentmondásos viszonynak az illusztrálására említhetjük

közel egymillió pedig havonta egyszer járt színházba (Párizs lakossága akkoriban haladta meg a kétmilliót). Frederic Hemmings, The Theatre Industry in Nineteenth-century France, (Cambridge: CUP, 1994), 325.

$11 \mathrm{Az}$ 1874-ben írt Histoire du vieux temps ('Hajdani idốk története'; bemutató: 1879. február 19., Troisième Théâtre-Français), a töredékesen fennmaradt La demande ('A kérés') 1875-ből, az 1878as La trahison de la Comtesse de Rhune (Rhune grófnô árulása) és az 1879-es Une répétition ('Próba', bemutató: 1904. május 6., roueni Normann színház).

Itt kell megemlítenünk az À la feuille de rose, maison turque ('A rózsalevelhez címzett török ház') című bohózatot, amelyet Maupassant Robert Pinchonnal közösen, nem publikálásra, hanem házi előadásra írt. A darabot 1945-ben Pierre Borel adta ki először. A bohózatot, melyet Maupassant anyjának írt 1875. március 8-i levelében „kimondottan érzéki darab”-ként („une pièce absolument lubrique”, kiemelés Maupassant-tól; lásd: MAUPASSANT, Correspondance, 1: 70-71, 71.) jellemzett, csupán kétszer mutatták be (1875. április 15-én Leloir, 1877. május 31-én pedig Becker műtermében), válogatott közönség előtt, amelynek soraiban ott ültek a „nagyok” is: Flaubert, Turgenyev, Zola, Goncourt. A női szerepeket beöltözött férfiak játszották, maga Maupassant egy odaliszkot alakított. A több mint pikáns, helyenként pornográf darab tartalmáról sokat elárul a cím, amely explicit módon Flaubert Érzelmek iskolája c. regényének bordélyára, Zoraïde - a „török nő” - házára utal. A címben rejlő implicit allúzió azonban a magyar olvasók számára nem, de még a frankofón olvasók egy része számára sem feltétlenül érezhető. A bohózatról, annak fogadtatásáról többet megtudhatunk Edmond Goncourt Naplójának aznapi bejegyzéséből.

12 Ennek ellenére Flaubert sem volt képes ellenállni a színház csábításának: az 1874-ben bemutatott Le Candidat ('A jelölt') címủ politikai színműve megbukott a Vandeville-színházban. A Maupassant-nak küldött példány ajánlása a következő: „Guy de Maupassant-nak/ Gustave Flaubert/ Fiatalember, szolgáljon ez tanulságul!!!”. „À Guy de Maupassant/ Gustave Flaubert/ Que cela, jeune homme vous soit un enseignement!! !” Idézi Matthieu DesPortes, „Exemplaire familial: la circulation du souvenir à travers les dédicaces", in Flaubert, Le Poittevin, Maupassant: Une affaire de famille littéraire, dir. Yvan LeCLeRC, (Rouen: Presses universitaires de Rouen et du Havre, 2002), 61-94, 91. 
a Rhune grófné árulása c. háromfelvonásos, verses történelmi drámájának genezisét. A dráma, amelynek első változata 1876-ban, végleges verziója 1877-78 telén született, nehezen készült el, Maupassant sokat szenvedett az írással. A darabot, ahogy egyébként minden elkészült művét, felolvasta Flaubert-nek, aki - fenntartásai ellenére - mindent megtett annak érdekében, hogy a Comédie Française műsorára tủzze. Ajánlására Maupassant felkereste Sarah Bernhardt-t, a színház vezető színésznőjét, aki állítólag el is olvasta az első felvonást, és megígérte, hogy Émile Périn, a színház programigazgatójának figyelmébe ajánlja a drámát. Nem tudni miért, de végül mégis Flaubert volt az, aki megmutatta Périnnek a szöveget. A mester közbenjárása ellenére a színdarabot nem mutatták be. Maupassant anyjának írt levelében ${ }^{13}$ annak a meggyőződésének adott hangot, hogy a gyakorlati ügyekben járatlan Flaubert nem volt elég határozott, és hogy az ő habozása ártott a darabnak. Alig egy hónappal későbbi levele arra utal, hogy túllépett a kezdeti sértődöttségén: „Nincs hírem a Théâtre-Français-ről, ami hidegen hagy, mert biztos vagyok benne, sok okból kifolyólag, amiket hosszú lenne kifejteni, hogy a darabomat nem fogják elfogadni." ${ }^{14}$ Barátjának írt áprilisi levelében viszont már az önreflexió is megjelent: „Majdnem az egész telemet arra vesztegettem, hogy újraírjam a drámámat, ami nem tetszik. Lesz...om a színházat: többé nem írok [színdarabot]." ${ }^{15}$ Fogadkozása nem bizonyult hosszú életűnek. Alig fejezte be a drámát, amikor a Tresse kiadó felkérte, hogy írjon egy rövid komikus jelenetet a Saynètes et monologues ${ }^{16}$ című kötetbe. Így született meg a 'Próba' (Une répétion) című egyfelvonásos, verses komédia, amelyben (mellesleg) a polgári szalonok amatőr színjátszását is kifigurázza.

1880-ban, miután a Gömböccel berobbant a francia irodalomba, Maupassant a versíráshoz hasonlóan a színműírással is felhagyott, mégpedig azért, hogy teljes egészében a prózának - eleinte a kisepikának, később egyre inkább a nagyepikának - szentelje magát. Rátalált végre saját múfajára, az elbeszélésre, amelyben paradox módon költői és drámaírói ambíciót is megvalósíthatta: legsikerültebb novellái azok, amelyekben ötvözte a lírai, drámai és epikai sajátosságokat. Mindazonáltal nem sokáig tudott ellenállni a színház csábításának: szinte első regénye, az Egy

13 Lásd: 1878. február 15-i levél. Maupassant, Correspondance, 1: 151-153, 151.

14 "Je n'ai pas de nouvelles du Théâtre-Français, ce qui me laisse froid, car j’ai la certitude que, pour beaucoup de raisons qu'il serait trop long de développer, ma pièce ne sera pas reçue.” Kelt 1878. március 21-én. Maupassant, Correspondance, 1: 154-156, 155.

15 „J'ai perdu presque tout mon hiver à refaire mon drame qui ne me plaît pas. Merde pour le théâtre : je n’en ferai plus." Robert Pinchonnak írt, 1878. április 23-i levele. (Kipontozás tőlem: Maupassant ebben a levelében is, ahogy általában, kiírja a nyomdafestéket nem tűrő szavakat.) MAUPASSANT, Correspondance, 1: 161.

$16 \mathrm{Az}$ 1879-ben megjelent kötet a későbbiekben sorozattá nőtte ki magát. 
asszony élete megjelenésével egy időben ${ }^{17}$ mutatták be a William Busnach ${ }^{18}$ által jegyzett Madame Thomassin címú egyfelvonásos drámát, amelyet a szerzőként feltüntetett Busnach Maupassant ötletéből, Maupassant közreműködésével írt. A korabeli kritikusok előtt Maupassant szerzősége nem volt titok, még akkor sem, ha az író nemcsak hogy nem vállalta fel a darabot, hanem egyenesen letagadta azt. ${ }^{19}$ Leveleiben és szépirodalmi műveiben továbbra is megjelent a színházművészet, valamint a társasági színjátszás kritikája. $A$ bajusz c. novella női narrátora például így bírálja a korabeli szalonkomédiákat:

[...] milyen buták ezek a mostanában divatos társasági darabok. Tele vannak erőszakoltsággal, esetlenséggel, durvasággal. Az élceik úgy puffognak el, mint az ágyúgolyók, szétrombolnak mindent. Nyoma sincs bennük az ötletességnek, a jókedvnek, az eleganciának. Ezek az írók igazán semmihez sem értenek. Fogalmuk sincs róla, hogyan gondolkoznak, hogyan beszélnek a magunkfajta emberek. [...] Szellemesség címén kaszárnyába való szójátékokat gyártanak; vidámság címén olyan szellemességet tálalnak föl nekünk, amelyet valahol a kültelken szedhettek föl, azokban az úgynevezett művészcsárdákban, ahol ötven esztendeje mindig ugyanazok a vad diáktréfák járják. ${ }^{20}$

Szereplőjének kritikája a szerző műfajjal szemben érzett fenntartásait fogalmazza meg: túl közhelyes, és hiányzik belőle az a finom és pontos jellem- és társadalomábrázolás, amely elbeszéléseinek egyik megkülönböztető jegye, de amelyet darabjaiban neki sem sikerült hitelesen megrajzolnia.

17 A regény először 1883. február 27. és április 6. között a Gil Blas c. napilapban jelent meg folytatásban. A darabot 1883. január 13-án mutatták be a Théâtre Clunyben. Négy este után azonban levették a műsorról, mert a színház vaudeville-hez szokott közönsége nem értékelte a gyászoló férj és a halott feleség egykori szeretőjének történetét. A fabula főbb elemei - a halott nő posztumusz levele, amely egy csapásra identitásokat rombol le és konstruál újra; idősebb férj és fiatal feleség boldogtalan házassága; a szerető a férj egy barátja - az író több novellájában ( $A$ végrendelet, 1882. november; Virrasztás, 1882. június; Oidipuszi történet, 1883. január), sőt első regényében is megjelentek már.

18 William Busnach (1832-1907) francia dramaturg, librettista. Legjelentősebb munkái Zola nagyregényeinek - Patkányfogó, Nana, Tisztes úri ház - adaptációi voltak.

19 Marlo Johnston angol irodalomtörténész 2005-ben találta meg és rendezte sajtó alá ennek a kiadatlan darabnak a szövegét. A kötet utószavaként írt tanulmányában Johnston összegyújtötte azokat a bizonyítékokat, amelyek Maupassant társszerzőségét alátámasztják, valamint bemutatta az író és Busnach kapcsolatát is. A kötet függelékében megtalálhatóak a darab bemutatása után megjelent kritikák is. Lásd: Guy de Maupassant, en collaboration avec William BusnaCh, Madame Thomassin, pièce inédite, éd. Marlo Johnston, (Rouen: Publications des Universités de Rouen et du Havre, 2005).

20 Guy de Maupassant, A bajusz, ford. Lányi Viktor, in Guy de Maupassant, Elbeszélések, 4 köt. (Budapest: Európa Könyvkiadó, 1979-1980), 2: 340. 
A nyolcvanas évek második felében több levele is arról tanúskodik, hogy Maupassant hosszú távú tervei között az szerepelt, hogy néhány év teljes alkotói szünet után eredeti, színpadra szánt komédiákat ír. Ugyanebben az időszakban, elbeszéléseivel és regényeivel párhuzamosan, néhány régebben megjelent novellája színpadra való átírásán dolgozott. Így született meg az ötletgazda Jacques Normand ${ }^{21}$ drámaíró közreműködésével a Musotte című komédia, amely Maupassant legsikeresebb színpadi műve lett. ${ }^{22} \mathrm{~A}$ hirtelen jött, minden valószínűség szerint már nem is várt színházi siker következményeként elbeszélései színpadi adaptációjának lehetősége valósággal felvillanyozta az akkor már nagybeteg írót. Jacques Normand-nak tőle szokatlan lelkesedéssel írta, hogy kétszáz novellája, amelyekben egy „remegő és vibráló emberiséget” alkotott, kiaknázandó „aranybánya”, ${ }^{23}$ melyből drámákat és komédiákat írhat. A betegség azonban közbeszólt, ${ }^{24}$ a nagyratörő tervekből csak egy befejezett - Házastársi béke $e^{25}$ és egy befejezetlen adaptáció, az azonos címú novellára épülő Yvette maradt fenn. ${ }^{26}$

21 Jacques Normand (1848-1931), író, költő, színmüíró.

22 A színdarab alapjául Maupassant A gyermek (1882) c. novellája szolgált. Habár Jacques Normand írta a színjátékszöveget, a Gymnase igazgatójának ez nem nyerte el a tetszését, így kérésére Maupassant átdolgozta Normand adaptációját. (Bemutató: Théâtre du Gymnase, 1891. március 4.) A darab, amelyet kritikusok és nézők egyaránt pozitívan fogadtak, végre meghozta az írónak a színpadi sikert, ami őt magát is meglepte: „Íme, sikeres drámaíró vagyok, és ez igencsak meglep, mert nem hiszem, hogy felfedeztem volna a híres dramaturgiai titkot, amely a regényírók számára megfoghatatlan” - írta Robert Pinchonnak 1891 márciusában. „Me voici auteur dramatique à succès, et rudement étonné de l'être, car je ne crois pas avoir découvert ce fameux secret dramatique, impénétrable pour les romanciers.” MaUPASSANT, Correspondance, 3: 203. A vígjátékot több európai országban is bemutatták. Magyarra Paulay Ede fordította, 1891. okt. 9-én mutatta be a Nemzeti Színház. A Vasárnapi újság a darab frivol, pikáns jellegét emelte ki: „Hát biz ez nagyon realisztikus egy darab, akár foglalatját, akár kidolgozását veszszük. Ügyesen van írva, a közönség elé tálalva, noha elég erős füszerrel és kaviárral.” Vasárnapi újság XXXVIII/42, (1891): 688.

23 „Une humanité frémissante, vibrante”, „une mine d’or”. Normand szavait Jules Claretie 1911. október 11-én megjelent cikkében idézte. Jules Claretie, „À propos de Musotte”, Le Temps, (1911. október).

24 Egyre romló fizikai állapota miatt 1891-ben Maupassant már alig írt valamit. 1892. január 7-én, sikertelen öngyilkossági kísérlete után doktor Blanche elmegyógyintézetébe került, ahol 1893. július 3-án halt meg.

25 La Paix du ménage. A szöveg Az ágy szélén (1883) és az Ujévi ajándék (1887) c. novellák alapján készült. Első verzióját Maupassant 1888-ban írta. 1890-ben ezt a szöveget dolgozta át, és új címet is adott neki. A darabot ebben a formában soha nem mutatták be. A darab végleges címe az elsô változat címéből született, és nem Maupassant-tól származik. A három évvel később bemutatott színjáték végső szövegét a korabeli kritikák szerint, Maupassant második szövegváltozatát felhasználva, ifjabb Alexandre Dumas írta. (Bemutató: Comédie-Française, 1893. március 6.)

26 Az 1884-ben publikált Yvette c. novella az 1882-es Yveline Samoris c. elbeszélés kibővített, átdolgozott változata. 
Befejezett és töredékes színdarabjaiból joggal következtethetünk arra, hogy az elbeszéléseiben tetten érhető írói fantáziáját a drámai közlésforma nagymértékben korlátozta. Azok az irodalomtörténészek, akik Maupassant színjátékait vizsgálták, egyetértenek abban, hogy az írónak, habár minden technikai tudása megvolt a színműíráshoz, nem sikerült alkalmazkodnia a színpadra állítás azon elemeihez, melyeket a korban népszerủ olasz színház hagyományai megköveteltek. Louis Forestier szerint a korabeli színház mint a trompe-l'œil művészete nem volt eléggé trompe-l'œil annak az illuzionistának, akinek a regényíró Maupassant tartotta magát. Forestier megállapítása Maupassant Péter és János című regényének előszavában - amelyet az író pszichológiai tanulmánynak nevezett - kifejtett „elméletére” reflektál, amely szerint a valószerűség a fikcionáltság egyik változata:

A valóság ábrázolása tehát azt jelenti, hogy a valóság tökéletes illúzióját kell adni, a tények mindennapi logikájának megfelelően, nem pedig szolgai módon másolni a tényeket, összevissza, ahogy egymásra következnek. Mindebből azt a következtetést vonom le, hogy a tehetséges realistáknak inkább az „illuzionista” nevet kellene viselniök. [...] mindegyikünk csak egy illúziót alkot magának a világról, költői, szentimentális, vidám, mélabús, szennyes vagy gyászos illúziót, aszerint, hogy milyen a természete. S az írónak nincs más hivatása, mint hogy visszaadja ezt az illúziót, mindazon művészi módszerek segítségével, amelyeket megtanult, s amelyekkel rendelkezik. ${ }^{27}$

Ezt az illúziót - és ennek Maupassant is tudatában volt - színdarabjaiban nem sikerült megteremtenie. Ezért is utasított el kategorikusan minden olyan felkérést, amely regényei színpadra való átültetésére vonatkozott. A színjáték komplex műalkotás, amelynek az írott szöveg csak egyetlen eleme. Színházi műalkotássá a drámaszöveg csak a befogadókkal az előadás - mint egyidejű és közvetlen kommunikáció - során válhat, feltéve, hogy a sok különböző hatáselem - verbális és nem verbális, vizuális, auditív vagy más módon érzékelhető és értelmezhető jelek - összhangban van az írott szöveg tartalmával és intenciójával. A színjátékszöveg tehát olyan színházi írásmódot feltételez, amelynek inherens jellemzője az, hogy már eleve rendelkezik a színpad egyfajta elképzelésével. Maupassant azonban, aki többször is a „stílusfogások művészete" ${ }^{\text {"28 }}$ kifejezést használta a színházművészettel kapcsolatban, nézőként sem hitt a színpadi illúzióban: „[...] a drámamúvészet oly

27 Guy de Maupassant, Péter és János, ford. Justus Pál, in Guy de Maupassant, Összes regényei, 2 köt. (Budapest: Európa Könyvkiadó, 1969), 2: 18.

28 „Art des ficelles.” A kifejezés többjelentésű: a francia ficelle szó nemcsak zsineget, zsinórzatot, de átvitt értelemben egy szakma vagy művészet - különösen a színházművészet - trükkjeit, fogásait is jelenti. 
kevéssé érdekel, életemben harmincnál többször nem jártam színházteremben, annyira érzéketlen maradtam a szcenikai konvenció iránt és hitetlen a tömérdek stílusfogás láttán, de nem kárhoztatom azokat, akik imádják." ${ }^{29}$

A fentiek alapján kijelenthetjük: az író életművének kronológiai vizsgálata azt bizonyítja, hogy a költészettel való szakításával ellentétben Maupassant a színháznak sosem fordított végleg hátat, drámaírói hajlama rövid pályája ${ }^{30}$ egészét végigkísérte, állandóan változó drámatervei és -szövegei prózai mûveivel párhuzamosan, azokkal kölcsönhatásban formálódtak. Azt is megállapíthatjuk, hogy legnagyobb színházi sikereit azokkal a drámaszövegeivel érte el, amelyeknek forrásai saját elbeszélései voltak. Ez az állítás még akkor is helytálló, ha színdarabjai között nemhogy remekművet, de időtálló művet sem találunk. Ennek ellenére a színműírás nem tekinthető felesleges kitérőnek vagy mellékvágánynak az író életművében. A drámaszövegek írása során olyan müfaji követelményeket, technikákat - pontos és koncentrált kifejezésmód; direkt jellemábrázolás, amelyben a szereplők szavai és gesztusai mutatják a jellemet; kidolgozott szituációk - sajátított el, amelyeket szépprózájában sikerrel tudott hasznosítani. Különösen igaz ez az elbeszéléseire, amelyekben a tömörség, a sűrítettség eleve müfaji követelmény.

A drámai és narratív stratégiák szintézisének, a műfaji keveredés produktivitásának szempontjából azok a novellák relevánsak, amelyek a két műnem átmeneteként, egyfajta drámai novellákként értelmezhetők. Az általunk dialógusos novelláknak nevezett kategóriába azokat a novellákat soroljuk, amelyek részben vagy teljes egészében drámaszöveg formájában íródtak. ${ }^{31}$

Maupassant 301 novellájából mindössze négyet sorolhatunk ebbe a drámai, dialógusos novella kategóriájába. Ezek, megjelenésük sorrendjében a következők: Luneau-né esete, $A z$ ágy szélén, Elégtétel és a Falusi bíróság. ${ }^{32}$

$29, \ldots, \ldots[$ l... [ lart dramatique m'amusait tellement peu que je n'étais pas entré trente fois dans mon existence dans une salle de spectacle, tant je demeurais insensible à la convention scénique et incrédule devant les énormes ficelles, mais je ne blâme pas ceux qui adorent cela.” Gérard DelAISEMENT, „Maupassant et la tentation du théâtre", Le Bel-Ami 5-6, (1957. március): 17-20, 18.

30 Maupassant írói pályája a Gömböc megjelenésétől sikertelen öngyilkossági kísérletéig alig több mint tíz évet ölel fel.

31 Ezeket a novellákat a francia nyelvú szakirodalom drámai vagy drámanovelláknak is nevezi. Mivel a drámanovella az 1890-es évek magyar kisepikáját elemző szakirodalomban általánosan elfogadott terminus technicus, amely leginkább olyan novellák megjelölésére szolgál, amelyek a tragikus fordulatra, a lélek belső drámájára, a drámai befejezésre helyezik a hangsúlyt, ezt a kifejezést tanulmányunkban nem használjuk.

32 A novellák eredeti címe és első megjelenésének időpontja: Le cas de Mme Luneau (1883. augusztus 21.), Au bord du lit (1883. október 23.), La revanche (1884. november 18.), Tribunaux rustiques (1884. november 25.). Maupassant novellaírói gyakorlatának megfelelően ez a négy elbeszélés is folyóiratban jelent meg először, és csak később foglalta be őket gyűjteményes köteteibe. Maupassant több lapnak is állandó munkatársa volt. Közismert az a tény, hogy az adott sajtóorgánum irányultsága 
A drámai forma legtisztábban az Elégtételben jelenik meg. A novella szövegét az író két jelenetre osztotta. Az első jelenet a férfi szereplő (a felszarvazott volt férj) monológja, amelyből megismerhetjük a második jelenetet alkotó (az exházaspár tagjai között zajló) dialógusban kibontakozó események előtörténetét, valamint a férfi ideális nőről alkotott képét. Ezen kívül a szöveg csak néhány, a helyszínre, a szereplők érzelmeire, mimikájára és mozdulataira vonatkozó didaszkáliát tartalmaz, melyek tipográfiailag (kurzív betûtípussal) is elkülönülnek a dialógustól. Ez utóbbiban nem a prózai művekben megszokott sor eleji gondolat- vagy idézőjellel jelzi az író, hogy egy szereplő éppen beszél, hanem a drámaszövegekre jellemző módon a beszélő szereplő nevét adja meg.

A szöveg, amit olvasunk, nemcsak formailag, hanem szemantikai struktúráját tekintve is valódi drámai szövegnek tekinthető, mivel benne a történet és a közlés síkja nem választható el egymástól, pontosabban a két sík azonos. Az Elégtételben minden közlés, minden magán- és párbeszéd a történeten belül hangzik el, azaz csak a történet részeként értelmezhető, szemben az elbeszélő szöveggel, amelyben a történet különböző elemei kizárólag a narrátor közlésében jelenhetnek meg. A második jelenet dialógusa is a drámai mûnemre jellemző párbeszéd. Ezt bizonyítja egyfelől a drámai dialógusra jellemző sajátos idő- és térrendszer, hiszen a szereplők az „itt és most” viszonylatában nyilvánulnak meg, másfelől ez a párbeszéd eseményeket eredményez, változás(oka)t eszközöl a beszélők között. A drámai és elbeszélői szövegben szereplő dialógusok elhatárolásának e kritériumát August Wilhelm Schlegel így fogalmazta meg:

Ha a személyek egymással ellentétes gondolatoknak és érzéseknek adnak hangot, ámde anélkül, hogy ez változást okozna beszélgetőpartnerük megygyőződésében, ha végül mindketten ugyanabban a lelkiállapotban maradnak, mint a beszélgetés kezdetén, akkor a párbeszéd tartalmilag figyelemre méltó lehet ugyan, de nem kelti fel az érdeklődést, mint a dráma. ${ }^{33}$

Ennek a műfajspecifikus elvárásnak az Elégtétel maradéktalanul eleget tesz. A férj, aki egykor brutálisan megverte az őt felszarvazó feleségét, találkozik volt nejével,

befolyásolta témaválasztását, elbeszéléseinek hangnemét. Ez a négy novella a Gil Blas politikai-irodalmi napilapban (1879-1940) jelent meg, amely csípős és pajzán szövegek publikálásával gyakran okozott botrányt. Maupassant is ebben a napilapban publikálta sikamlósabb tematikájú vagy nyelvezetû elbeszéléseit, amelyek közé a korpusz szövegei is sorolhatók. Ennek tükrében különös jelentőséget kap az a tény, hogy az Elégtétel c. novella női szereplője egy hotelben, nyilvános helyen a Gil Blas-t olvassa. Ez a fogás nemcsak kikacsintás a lap olvasóira, de a jellemábrázolás eszköze is egyben, azt bizonyítja, hogy a nő szabadszellemû, független és nem túlzottan szemérmes.

33 August Wilhelm Schlegel, „A drámai müvészetrôl és irodalomról”, in August Wilhelm SCHLegel és Friedrich Schlegel, Válogatott esztétikai írások, ford. Bendl Júlia és TANDori Dezső, (Budapest: Gondolat, 1980), 603. 
és hosszú dialógusuk végére nemcsak hogy megbocsátást nyer, de sikerül rávennie a nőt, hogy csalja meg második férjét, természetesen vele. Maupassant szövegében a drámai dialógusnak ez a megkülönböztető jegye szorosan összekapcsolódik a drámai szöveg másik lényegi velejárójával, a konfliktussal. A dráma ugyanis olyan műnem, amelyben elvek, világképek, értékrendek ütköznek. Maupassant szövege már a két szereplő közötti interperszonális kapcsolat révén előrevetít egyfajta összeütközést, konfliktust a férfi és a nő házassághoz, házastársi hűséghez, megcsaláshoz való viszonyának szintjén, ami párbeszédükben ki is bomlik, majd a dialógus végére feloldódik: a nő megadja magát. A történet mozgalmasságának hiányát a két szereplő által vívott szópárbaj, a szellemes - saját korában pikáns párbeszéd, a szereplők jelenben változó viszonya pótolja. Mindezek alapján joggal jelenthetjük ki, hogy az Elégtétel valójában nem elbeszélés, hanem egy igazi saynète. ${ }^{34}$

Adja magát a feltételezés, hogy az író azért választotta a drámai formát, mert abban reménykedett, hogy egy színházigazgató felfigyel rá; esetleg ő maga akarta színpadra állítani saját villájában vagy valamelyik általa is látogatott párizsi arisztokrata vagy nagypolgári szalonban. De az is lehet, hogy „csak” kísérletezett a műfajjal: ki akarta próbálni, hogy az alapvető drámai alkotóelemek - mint például a konfliktus, a feszültség, a párbeszéd - megfeleltethetők-e a novella műfaji sajátosságainak. Egy ilyenfajta kísérletezéshez tökéletes hátteret biztosított számára a napilap, amelylyel szerződése volt. Felmerül a kérdés, hogy Maupassant miért elbeszélésként és nem komédiaként aposztrofálta ezt a szövegét. Mivel a mű keletkezéséről semmit nem tudunk, így ezt a kérdést lehetetlen megválaszolni, ugyanakkor Maupassant színházhoz füződő ambivalens viszonyának tükrében a megjelölés egyáltalán nem meglepő. ${ }^{35}$ Azt se felejtsük el, hogy Flaubert példájából okulva Maupassant azt is megtanulhatta, hogy milyen sokat árt a színházi bukás egy mégoly sikeres írói karriernek is. Joggal feltételezhetjük, hogy ez magyarázza nemcsak azt, hogy ezek a szövegek novellaként jelentek meg, hanem azt is, hogy miért nem vállalta fel az író a Madame Thomassine társszerzőségét.

$A z$ ágy szélén esetében a múfaji meghatározás problematikusabb, mert ez az elbeszélés már rövid narratív szövegrészeket is tartalmaz, nemcsak a mû elején, de magában a szövegben is. A magyar kiadás szövege alapján az a feltételezés tűnhet

34 Maupassant korábban már kísérletezett ezzel a 19. századi Franciaországban rendkívül népszerủ múfajjal. Lásd: 16. lábjegyzet.

35 Két évvel az első megjelenése után ez a novella bekerült a Nouveau Décaméron ('Új Dekameron') címú többszerzős antológiába, amelyben a boccacciói hagyománynak megfelelően tíz személy - a kor híres írói és néhány hölgy - történeteket mesélnek egymásnak. Az elbeszélés átdolgozott változata a hetedik, a „szerelem a színházban” témának szentelt napon hangzik el. A keretben szereplőként megjelenő Maupassant azért mentegetőzik, mert nem ismer a megszabott témához illő mesét. Ezért felajánlja, hogy a társaság színésznő tagjával előad egy rögtönzött komédiát; a fikció szerint ez lesz az Elégtétel. Lásd: Nouveau Décaméron, 10 köt., (Paris: E. Dentu, 1884-1887). 
helytállónak, hogy elbeszélésről van szó: ebben az esetben ezek a szövegrészek heterodiegetikus narrációt feltételeznek, amelybe ékelve az egyenes beszéd, rövid elbeszélői kísérőszöveggel vagy kommentárral, megjelenik. A párbeszédek tipográfiája is ezt a feltételezést támasztja alá. Maupassant összes elbeszélésének francia kritikai kiadása ezzel szemben ezeket a szövegrészeket kurzívval szedi, aminek következtében a narratív szövegrészek didaszkáliaként interpretálhatóak. ${ }^{36}$ Annál is inkább, mert bár nemcsak rövid mondatokat, hanem egész bekezdéseket is találunk köztük, ezek nem lépnek túl a szerzői utasítások azon funkcióján, hogy az olvasót tájékoztassák azokról a dolgokról, amelyek nem vagy hihetően nem építhetők be a dialógusba. ${ }^{37}$ Ebben a múben is eltérő értékrendek csapnak össze: a megcsalást a házasság velejárójának tekintő férfi (feltéve, hogy nem ő a megcsalt fél) és a házastársi hűséget fontosnak tartó nő (feltéve, ha nem ő a megcsaló fél) értékrendje. De Maupassant még egyet csavar a konvencionális morális dilemmán: az elbeszélés mozgatórugója az az implicit kontraszt, amely a házasság korabeli erkölcsi megítélése és a szereplők viselkedése között feszül. A férj, akit felesége szándékosan féltékennyé tett, természetesnek tartja, hogy az eddig elhanyagolt és megcsalt feleség a karjaiba omlik, és teljesíti házastársi kötelességét. A nő azonban feltételeket szab: ha a férj azt akarja, hogy ôt részesítse előnyben hódolójával szemben, akkor ugyanaz a honorárium illeti meg, mint férje korábbi szeretőit. A férj először tiltakozik, mondván, nem hülye, hogy törvényes feleségének fizessen, de a nő (és a vágy) legyőzi ellenállását: „- Hát, nesze, te... te! Hatezer! De aztán... [...] Nehogy megszokd! A grófné felnevet, a férfi felé fordul. - Havonként ötezer, uram, vagy visszaküldöm a kokottjaihoz. Sőt... ha elégedett lesz... még emelek is!"38 A dialógus szellemes és a kortárs olvasók számára kellően pikáns, a csattanó hatásos, a szöveg határozottan színpadra kívánkozik. ${ }^{39}$

A Luneau-né esete és a Falusi biróság sok szempontból is párhuzamba állítható egymással. Tematikailag mindkettő a szakirodalom által csak bíróságnovelláknak (contes $d u$ prétoire) nevezett csoportba tartozik. Az ebbe a típusba sorolt novellák sajátossága az, hogy a narrációnak külön megszabott tere van - ez az elbeszélő

36 A kurzív csak a novella kötetben (Parent úr) publikált szövegében tűnt fel, a két évvel korábbi Gil Blas-ban megjelent első kiadásban még nem. Maupassant időközben talán meggondolta magát, és úgy döntött, hogy ezzel a technikával az újraközölt szöveg drámai jellegét hangsúlyozza.

37 Lásd: BÉcsy Tamás, A dráma lételméletéról, (Budapest: Akadémiai Kiadó, 1984), 216.

38 Guy de Maupassant, Az ágy szélén, ford. IllÉs Endre, in Guy de Maupassant, Elbeszélések, 4 köt. (Budapest: Európa Könyvkiadó, 1979-1980), 2: 482.

39 Ahogyan azt már említettük, ez az elbeszélés Maupassant egyik színdarabjának az alapjául szolgált. Lásd: 25. lábjegyzet. A darab vége azonban drasztikusan eltér a novella borsos csattanójától: kiderül, hogy meghökkentő ajánlatával a feleség csak próbára tette a férjét, aki ezen az erkölcsi próbatételen elbukott, amikor nejét az örömlányok szintjére degradálta. A darab, Maupassant-tól szokatlan módon, erkölcsi tanítással zárul. 
szövegekben rendszerint nem bír döntő jelentőséggel -, amely a témával együtt implikálja a drámai szövegre jellemző dialogikus formát. A drámai szöveg formai követelményei mindkét mủben a párbeszéd tipográfiájában és a párbeszédhez tartozó didaszkáliák kurzív kiemelésében jelennek meg. A korpusz elbeszélései közül ezek tartalmazzák a leghosszabb és leginkább elbeszélő jellegű szövegrészeket, amelyek a fent tárgyalt $A z$ ágy szélén című elbeszéléssel szemben nem interpretálhatóak szerzői utasításként. Ezek a bevezető narratív szövegrészek egyfajta preambulumként funkcionálnak, bemutatják a békebírót és a vitás feleket, sőt a második novella még a tárgyalóterem szagát is rendkívül érzékletesen leírja.

Mindkét novella vígjátéki szituációra épül. Az elsőben egy özvegyasszonynak a hőn áhított örökség miatt mindenáron gyereket kell szülnie, ezért, fizetség ellenében, felfogadja a vaskereskedő sekrestyést, hogy segítse hozzá célja eléréséhez. A nő teherbe esik, és ekkor jön a váratlan fordulat: Luneau-né nem akarja kifizetni a megígért összeget, mert a férfi a rossz nyelvek szerint meddő, törvényes gyermekei sem tőle fogantak, ezért a nő időközben több férfi szolgálatát is elfogadta, akik ráadásul ellentételezést sem kértek tőle. A második elbeszélés panaszosa egy idősödő, jómódú parasztasszony, aki tizenöt éven keresztül tartott a szolgálatában - és ez alatt ne csak munkavégzést értsünk - egy fiatal parasztlegényt. Amikor munkaadója öregedni kezdett, a közben férfivá érett Isidore ki akart lépni, de egy kis földbirtok fejében elszegődött még öt évre. Az öt év lejártával a férfi megházasodott, a csalódott asszony pedig nem akarja átengedni neki a szerződésbe is foglalt földadományt.

A két bíróságnovella, jellegéből adódóan, két szükségszerűen ellentétes álláspontot ütköztet, bennük a pereskedő felek szájából elhangzó érvek és ellenérvek egymásnak feszülő kontrasztja, kiegészítve a békebíró kérdéseivel és ítéletével, jelenti magát az eseményt. A Falusi bíróság című novellában Maupassant már a két viszálykodó fél nevével is sugallja a drámai szövegek műfajspecifikus jellemzőjét, az érdekellentétet: a beszélő nevek használata egyértelműen a jellemábrázolás felé tolja el a novellát. ${ }^{40}$ Mindkét elbeszélés a középkori farce hagyományaiból merít, annak elemeiből építkezik, de a Falusi bíróságban ez az örökség sokkal hangsúlyosabb..$^{41}$ A farce, amellett hogy nevetséges helyzetre vagy csattanóra épül, gyakran ábrázol durva helyzeteket, használ népi fordulatokat és trágár vagy borsos kifejezéseket. Ennek tükrében helytállónak látszik Louis Forestier azon feltételezése, hogy a Luneau-né esete címû novellában szereplő'eset' szót nem csak jogi értelemben

40 A fiú családneve Paturon, amely a pâture szóból származik, jelentése 'legelő’. A faképnél hagyott nő Bascule-né, neve a basculer (inog, felborul, felbillen) igéből képzett. Ez a szó az ófrancia baculer igére vezethető vissza, ami 'elfenekelést' és 'közösülést' is jelent.

$41 \mathrm{Az}$ egyetlen magyar nyelvű Maupassant-monográfia szerzője, Szentkuthy Miklós szerint a farce, a „latin, ôs-örök bajazzó-kedv" az író mûveinek - minden művének - egyik inherens eleme. SzENTKUTHY Miklós, Maupassant egy mai író szemével, (Budapest: Gondolat, 1968), 21. 
kell(ene) értelmeznünk. ${ }^{42}$ A farce szereplői általában negatív - hiszékeny, ravasz, képmutató, kapzsi, zsugori stb. - típusok, akik természetesen elnyerik méltó büntetésüket: felsülnek vagy átverés áldozatai lesznek. Luneau-né „időveszteség és

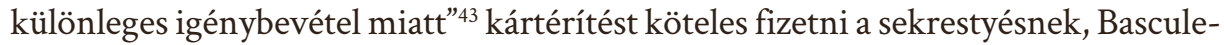
né pedig, miután elvesztette a szeretőjét, elveszti a földjét is.

A maupassant-i komikum vagy farce mögött azonban, minden bizonnyal pesszimista világnézete miatt, gyakran felsejlik valami nyomasztó, kegyetlen vagy éppen tragikus árnyék. Nincs ez másképp a vizsgált novellák esetében sem. Az Elégtételt nyitó monológ, a sikamlós történetbe ágyazva, az ismeretlen, elérhetetlen ideális nő iránt érzett kínzó, már-már rögeszmés vágyat fogalmazza meg. Az ágy szelén a kihűlt házasság felmelegítésének receptjét annak fizetett szolgáltatássá degradálásában látja és láttatja. A Luneau-né esete hátterében a Maupassant elbeszéléseiben rögeszmésen visszatérő törvénytelen - vagy törvényesnek hitt törvénytelen - gyermek témája sejlik fel. A Falusi bíróság explicit módon a „minden ember megvehető” elvet illusztrálja, igaz, nem a korabeli irodalmi művekben megszokott, közhelynek számító pénzen vett nő sztereotípiáját, hanem a pénzért megvehető férfit, pontosabban fiút állítja a középpontba. Az elbeszélésben ugyanakkor implicit módon az író mûveinek egy másik vezérmotívuma, az öregedéstől való félelem idéződik meg.

Békebíró (mosolyogva): Szedje össze magát, kedves asszonyom. Nocsak, nocsak, szedje össze magát... és... ha... megengedi, hogy valami jó tanácsot adjak magának... keressen egy másik... tanítványt...

Bascule-né (a könnyein át): Úgyse találok... úgyse...

Békebíró: Igazán sajnálom, hogy nem ajánlhatok egyet. ${ }^{44}$

Ez az idézet is azt mutatja, hogy ezek az anekdotikus vagy a farce jellegzetességeit magukon viselő, csattanóra kihegyezett novellák morális tartalmukban túlmutatnak önmagukon, a kacagás mögött társadalmi vagy belső drámák húzódnak meg, amelyeknek a novellákban, az Elégtétel kivételével, szövegszerủen szinte semmi nyoma nincs. A befogadó az, aki a történeteket értelmezi, és a dialógusok, valamint a szereplők belső logikája által kijelölt gondolatmeneten végighaladva azonosíthatja, felfejtheti és továbbgondolhatja azokat.

$42 \mathrm{Az}$ eredeti címben szereplő cas szó a férfi és a női nemi szervet egyaránt jelöli. Annak tükrében, amit Maupassant szexualitáshoz füződő viszonyáról tudunk, kevéssé hihető, hogy ne ismerte volna a szónak ezt a jelentését. A szó e jelentését lásd: Alfred DeLVAU, Dictionnaire érotique moderne, par un professeur de langue verte, (Bâle: Imprimerie de Karl Schmidt, dátum nélkül), 83.

43 Guy de Maupassant, Luneau-né esete, ford. Somogyi Pál László, in Guy de Maupassant, Elbeszélések, 4 köt. (Budapest: Európa Könyvkiadó, 1979-1980), 2: 397.

44 Guy de Maupassant, Falusi bíróság, ford. Rónay György, in Guy de Maupassant, Elbeszelések, 4 köt. (Budapest: Európa Könyvkiadó, 1979-1980), 3: 433. 
Összegzésképpen elmondhatjuk, hogy a négy dialógusos novella tematikai szempontból, valamint hangulatát, nyelvezetét tekintve is különbözik egymástól. A drámai írásmód formai jegyei, ahogyan azt fentebb bemutattuk, szintén eltérő módon és mértékben jelennek meg bennük. Mindazonáltal a négy szöveg az elemzés szempontjából releváns közös jellegzetességeket is mutat: a vizsgált elbeszélésekben az író látszólagos közvetítetlenséggel mutatja meg az eseményeket és karaktereket, kerüli a direkt leírást, a szereplőket nem egy narrátor, hanem gesztusaik, beszédmódjuk, szókincsük, megszólalásuk jellemzi. Szereplői dialógust vagy szópárbajt folytatnak egymással, néhány tûpontos kifejezéssel megrajzolt díszletben mozognak, gesztikulálnak. Az elbeszélő művekre jellemző cselekményesség eltűnik, helyette a szereplő egyéniségének belső logikája vagy egy másik szereplővel való párbeszéde lesz a változás mozgatórugója. Mindez Maupassant regényről, regényírásról alkotott felfogásának a következménye: szerinte az írónak, amikor a szereplőit beszélteti, el kell rejtenie a hangját, a stílusát, és hagynia kell a szereplőit saját, egyéni hangjukon beszélni.

A dráma és epika határán íródott rövid dialógusos novellák szövegvizsgálata azt bizonyítja, hogy Maupassant prózaesztétikája, a látni és láttatni, azaz a pontosan látni és pontosan láttatni elve az, ami leginkább megfelel a drámai írásmód követelményeinek. Az író dialógusos novellái a valóság tökéletes illúziójára való maupassant-i törekvés végső következményének és egyben betetőzésének tekinthetők.

\section{Résumé}

Guy de Maupassant, en tant qu'auteur des pièces de théâtre, est totalement inconnu en Hongrie. La présente étude a pour objectif de présenter l'influence de l'écriture théâtrale sur les nouvelles du romancier, en analysant les nouvelles prenant - entièrement ou en partie - la forme dramatique. Les quatre nouvelles dialogiques de Maupassant, notamment Le cas de Mme Luneau, La revanche, Au bord du lit et Tribunaux rustiques sont nées à la croisée de deux genres, le drame et la nouvelle. L'article vise à examiner les spécificités formelles et sémantiques de ces nouvelles, caractéristiques aux deux genres différents. 